\title{
Development of HOTS (Higher Order Thinking Skills) Test Instrumen in the Maritime History Course based on Riau Local History
}

\author{
Bunari $^{1}$, Asyrul Fikri ${ }^{2}$, Yanuar Al Fiqri ${ }^{3}$, Nurhijrah Bt. Zakaria ${ }^{4}$, Jafalizan Md. Jali ${ }^{5}$ \\ \{bunari@lecturer.unri.ac.id ${ }^{1}$, asyrul.fikri@lecturer.unri.ac.id ${ }^{2}$, \\ yanuar.al@ lecturer.unri.ac.id ${ }^{3}$, nurhijrah@ipgm.edu.my ${ }^{4}$, jafalizan@uitm.edu.my $^{5}$ \}
}

Riau University, Indonesia ${ }^{1}$, Riau University, Indonesia ${ }^{2}$, Riau University, Indonesia ${ }^{3}$, Institut Pendidikan Guru Kampus Dato' Razali Ismail, Malaysia, ${ }^{4}$ Universiti Teknologi Mara, Malaysia ${ }^{5}$

\begin{abstract}
The purpose of this research is to develop HOTS base test instrumen in the Maritime History Course based on Riau Local History. The method used in this research is research and development (R\&D). The research data was obtained in two ways, namely, interviews and literature. After the data is obtained, it is continued with the preparation of HOTS-based learning evaluation instruments. The type of instrument used is a HOTS-based learning outcome test. The instrument development began from the preparation of the test items to the examination of items by material experts Items that are declared valid will be retained and invalid items will be revised/discarded. The next step is to test the reliability of the items. Base on the result of Validity and Reliability of test instrument that has been developt, indicate that the test instrumen can be use to measure the learning outcome of Maritime history course in the Departmen of History Education University of Riau.
\end{abstract}

Keywords: Development, HOTS, Maritime History, Local History, Riau

\section{Introduction}

Teaching and learning activities at the college level are part of the student process in studying certain subjects. Each course has a goal or competence that students are expected to possess after completing lecture activities in that course. To find out whether or not the teaching objectives have been achieved and the quality of the teaching and learning process that has been implemented, it is necessary to conduct an assessment or evaluation of student learning outcomes. The benefit of evaluation in learning is to find out how far the students' understanding is related to the material that has been taught. In addition, it can also determine the quality of the learning program that has been implemented by analyzing the parts that are still weak and must be improved. The form of evaluation can use test data collection techniques developed in the form of learning outcomes evaluation instruments.

The instrument can be in the form of a test or a non-test. Tests can be in the form of objectives and essays, while non-tests can be in the form of observation sheets or questionnaires, attitude scales, match lists, and graded scales. Objective tests can be in the form of short answers, true-false, matchmaking, and multiple-choice with various variations: ordinary, relationships between things, complex, case analysis, graphs, and table figures. A description test which is also called a subjective test can be in the form of a free, limited, and 
structured description test [1]. Furthermore, for the preparation of test or non-test instruments, a teacher must refer to the guidelines for the preparation of each type and form of tests or nontests so that the instruments compiled meet the requirements of a good instrument, at least the basic requirements of a good instrument, namely valid (legitimate) and reliable (can be trusted) [2].

The development of evaluation instruments is generally applicable to all courses in universities. Among them are maritime history courses. This course has an academic contribution for students to know the maritime world of Indonesia in general and the East Coast of Sumatra or the area that used to be the territory of the Malay Sultanate. The scope of the study is from prehistoric times to contemporary. Learning Maritime history has an important function as remembering the identity of the Indonesian nation as the largest archipelagic country in the world is closely related to maritime life. Although the dominance of the sea as a natural factor is so great it is not always in line with the development of its culture. Indonesian culture is currently far away from marine or maritime culture, Indonesian culture now tends to lead to a cultural pattern that is only oriented to land, namely a culture characterized by characteristics such as a lack of knowledge about the sea compared to land, the dominance of the economic orientation of the land over the sea, meaning a system of marine mythology that often reduces people's courage to go to sea and the view that the sea is a dividing medium, not a link [3]. The study of maritime history is inseparable from the study of local history [4]. Local history itself can be understood as the study of people's lives or especially the community of a certain surrounding environment in the dynamics of its development on various aspects of human life. The geographical boundaries of this local history can be in the form of ethnic residences that are at the level of the second and first-level administrative areas but can also be limited to one city or even a village [5][6]. This is to strengthen students' understanding of local history within the framework of Indonesian national history. Local history explains in detail historical events that are not accommodated in national history. Understanding local history strengthens the identity of a heterogeneous and multicultural Indonesian nation and is spread over several regions. As a multicultural country, Indonesia is required to always be anticipatory and responsive to phenomenal forms that can damage this harmony [7]. By studying local history, students will gain more knowledge related to Indonesia's socio-cultural diversity [8]. Indonesia's diversity which is represented through many local cultures must always be explored and maintained and integrated into all aspects of life, including education and teaching. These local cultures, if successfully strengthened and maintained, will at the same time strengthen Indonesia's national identity [9]. Local history also plays a role as a knowledge that strengthens understanding related to events that occur on a national historical scale. It is hoped that by understanding local learning, students will not only act as spectators and connoisseurs of the past but also have the potential to become historical actors in the present and the future, although only limited to their respective localities [10]. Local history holds the main position because it deals with the immediate environment and culture of students. This local history material becomes the basis for the development of students' personal, cultural and social identities. It can be seen that students first get to know the culture in their surrounding environment compared to those who are far away in areas outside their area. So we need a developer that starts from local things to create pride in the surrounding environment [11].

To introduce and attract students' interest in local historical events that occur in the area they currently live in, it is necessary to develop HOTS questions to measure and determine the extent of students' understanding of maritime history courses in local history studies in Riau Province. HOTS is very important to be integrated into the learning and assessment process 
because it can hone thinking skills that are very important for students. These thinking skills include critical thinking skills, creative thinking, and problem-solving. These three abilities are part of 21 st-century skills that need to be instilled to prepare students to face technological advances and globalization because in the 21 st-century students will be dealing with the flow of digital and information technology. For this reason, students need to be trained to become good thinkers. If students when dealing with the large flow of information are not able to think intelligently and openly, they will be unable to sort out which information is good and correct. Therefore, the role of educational institutions from basic to higher education is to instill these skills. Teachers and lecturers as the frontline in efforts to educate students are required to be role models and guides [12][13] [14].

Embedding HOTS into learning assessments can be applied through the creation of learning outcomes assessment questions that are based on HOTS. According to Wahidmurni [15], the steps for compiling HOTS questions are the same as the steps in preparing nonHOTS questions, only the emphasis is on the existence of contextual stimuli with the expected behavior in HOTS questions. In non-HOTS questions, a stimulus is also needed, but more questions are prepared without using a stimulus. The steps for preparing the HOTS questions are as follows:
a. Analyzing KD and KI
b. Compile a grid of questions.
c. Determine contextual and interesting stimuli
d. Write question items according to the question grid
e. Determine the answer key or scoring guidelines (rubric)

\section{Methodology}

The method used in this research is research and development (R\&D) which adopts the 4D (Four-D) development model. With research stages, namely, define, design, develop, and dissemination [16]. In this study, the 4-D model was modified so that the research stages were carried out until the development stage. Broadly speaking, research and development consist of three stages, namely:

1. Define: at this stage, a literature study is carried out by analyzing the material from both courses (Maritime History and Local History) to find which parts of the material can be integrated into learning outcomes assessment instruments

2. Design: at this stage the selection of the form of the instrument test to be made and the process of compiling an integrated maritime history assessment instrument grid for Riau local history based on High order Thinking skills.

3. Develop: This stage includes the preparation of narratives about learning outcomes tests, as well as conducting trials to determine the validity and reliability values of each of the questions that have been prepared.

This research was carried out at the Department of History Education Program, University of Riau Indonesia, carried out from June to October 2021. The data collection process that will be used to determine what material will be developed into learning outcomes assessment questions and the process of compiling the assessment instrument grid, is carried 
out by two ways, namely the process of literature study and interviews. The interview process was carried out to lecturers who are in charge of local History and maritime history courses to obtain lecture materials which include teaching modules, lesson plans, and syllabus. After the material is obtained, it is continued with a literature study which is carried out by analyzing the material for each course, syllabus, and lesson plan. This activity is carried out to find similarities in teaching materials so that the process of integrating local History materials which will be developed into test questions to assess the learning outcomes of maritime history courses can be carried out properly and appropriately.

To ensure that the items for assessing learning outcomes that have been made can be used to measure the level of success in learning outcomes for students taking maritime history courses, it is necessary to test the validity and reliability of the learning outcomes instruments that have been prepared. Validity describes the extent to which the measuring instrument (test) measures what it is intended to measure [17]. Establishing the validity of a test or instrument test is very difficult, especially because psychological variables are usually abstract concepts, such as intelligence, anxiety, and personality. These concepts have no concrete reality so that their existence must be inferred through indirect means [18].

Reliability shows the stability and consistency of a measurement instrument and can help estimate the goodness of measurement so that data consistency or accuracy is obtained. Broadly speaking, there are two types of reliability, namely internal and external reliability [19][20]. A test can be said to be reliable if it always gives the same results when tested on the same group at different times or on different occasions. The reliability carried out in this study is internal reliability. The calculation of the reliability of the instrument in this study uses KR20, which is a test used to answer true and false (dichotomies) about historical material where the test score is given is 1 for respondents who are correct and a score of 0 for respondents who answer incorrectly. The HOTS-based Riau history learning evaluation instrument will be declared suitable for use if it has succeeded in getting the reliability test results with the minimum criteria sufficient and the maximum criteria very high.

\section{Finding and Discussion}

Following the research method used to produce valid assessment instrument items, namely 4-D. So here are the steps that have been taken. In the first stage, a preliminary analysis was carried out to describe the condition of the lectures which included the composition of the syllabus and lesson plans as well as the books that became learning resources in maritime history and local history courses, this process was carried out to find similarities in teaching materials so that the integration process of local history materials will be developed into test questions to assess the learning outcomes of maritime history courses. In the process of analyzing the syllabus and lesson plans, four local history materials were obtained which would later be used as guidelines for preparing questions. The four submaterials of local history include 1) Natural conditions and geographical location of the Riau region, 2) Political-Economic Life of the Ancient Kingdoms in the Riau region, 3) Dutch colonialism in the Riau region and its implications for local kingdoms, 4) The establishment of Riau Province and its role in the progress of the Indonesian economy.

After the materials taught in the Riau history course are obtained, the next step is Design, which includes the process of compiling the assessment instrument grid and writing instrument items. As found in the first stage, a grid of Maritime history learning outcomes assessment instruments that are integrated with Local History based on High Order Thinking Skills has been compiled as follows: 
Table 1. HOTS based Maritime History assessment grid integrated with Local History

\begin{tabular}{llc}
\hline Course & \multicolumn{1}{c}{ Indikator } & Number of \\
& & question \\
\hline & Natural conditions and geographical location of the Riau & 5 question \\
& Region & \\
& Politics-Economy of Ancient Kingdoms in Riau Region & 10 question \\
Maritime & & \\
History & $\begin{array}{l}\text { Dutch colonialism in the Riau region and its implications } \\
\text { for local kingdoms }\end{array}$ & \\
& & \\
& Formation of Riau Province and Its Role in Indonesia's & 5 question \\
Economic Progress & 30 question \\
\hline
\end{tabular}

The next step is to develop learning outcomes assessment questions that are guided by the grid that has been prepared previously. The form of questions that will be developed are multiple-choice questions and are based on high-order thinking skills. This means that the questions made are prepared based on the rules for the preparation of the HOTS questions, which must have a stimulus. Stimulus is the basis for understanding information. In the context of HOTS, the stimulus presented must be contextual and interesting. A stimulus can come from global issues such as issues of information technology, science, economy, health, education, infrastructure, and others. A stimulus can also be sourced from problems that exist in the environment around the school such as culture, customs, cases in the area, or various advantages found in certain areas. A good stimulus contains some information/ideas, which is needed to develop the ability to find relationships between information, transfer information, and be directly related to the main question [22].

The next step is the process of testing the instrument as well as measuring the level of validity of each item statistically. In this case, the process of testing the instrument was carried out on students of the History education study program at FKIP, Riau University who had passed the Maritime History course. The item validity process will use the Point biserial Correlation statistical formula with the help of the Microsoft Excel program. The results of the validity of the items can be seen in the following table: 
Tabel 2. Validity result of Test Instrument

\begin{tabular}{cccc}
\hline Question & rValue & rTable & Result \\
\hline 1 & 0,353 & 0,361 & Drop \\
2 & 0,415 & 0,361 & Valid \\
3 & 0,426 & 0,361 & Valid \\
4 & 0,489 & 0,361 & Valid \\
5 & 0,405 & 0,361 & Valid \\
6 & 0,404 & 0,361 & Valid \\
7 & 0,384 & 0,361 & Valid \\
8 & 0,452 & 0,361 & Valid \\
9 & 0,021 & 0,361 & Drop \\
10 & 0,415 & 0,361 & Valid \\
11 & 0,494 & 0,361 & Valid \\
12 & 0,560 & 0,361 & Valid \\
13 & 0,438 & 0,361 & Valid \\
14 & 0,529 & 0,361 & Valid \\
15 & 0,508 & 0,361 & Valid \\
16 & 0,401 & 0,361 & Valid \\
17 & 0,353 & 0,361 & Drop \\
18 & 0,374 & 0,361 & Valid \\
19 & 0,397 & 0,361 & Valid \\
20 & 0,380 & 0,361 & Valid \\
21 & $-0,101$ & 0,361 & Drop \\
22 & 0,386 & 0,361 & Valid \\
23 & 0,322 & 0,361 & Drop \\
24 & 0,560 & 0,361 & Valid \\
25 & 0,374 & 0,361 & Valid \\
26 & 0,577 & 0,361 & Valid \\
27 & 0,438 & 0,361 & Valid \\
28 & 0,036 & 0,361 & Drop \\
29 & 0,403 & 0,361 & Valid \\
30 & 0,407 & 0,361 & Valid \\
\hline & & & \\
\hline
\end{tabular}

From the results of the analysis of the validity of 30 items that have been compiled. It turned out that there were six questions that were declared invalid. The six questions are questions number $1,9,17,21,23$, and 28 . The results of the calculation of the validity of the six questions show the value of rcount which is below the threshold of rtable. Therefore, these six questions were deleted and could not be used to assess student learning outcomes 
After the valid questions are obtained, the next step is to calculate the reliability of the valid questions. Reliability is calculated using the KR20 formula. Here is the KR20 calculation formula:

$$
\begin{gathered}
r_{i i}=\frac{\mathrm{k}}{\mathrm{k}-1}\left[1-\frac{\Sigma \mathrm{pq}}{\sigma_{t}^{2}}\right] \\
\mathrm{rii}_{\mathrm{i}}=\frac{34}{34-1}\left[1-\frac{7,30}{39,34}\right] \\
=0,838
\end{gathered}
$$

Calculation of the reliability of the instrument produces a value of 0.863 . This value is then compared with the reliability table to find out the resulting reliability criteria.

Table 3. Reliability Interpretation table

\begin{tabular}{cc}
\hline rValue & Interpretation \\
\hline $0,800-1,000$ & Very High \\
$0,600-0,799$ & High \\
$0,400-0,599$ & Sufficient \\
$0,200-0,399$ & Low \\
\hline
\end{tabular}

Based on the interpretation table above, it can be stated that the instrument questions for the assessment of learning outcomes for maritime history courses that are integrated with local history based on HOTS have very high reliability.

The results of the analysis show that the HOTS-based questions that have been developed have passed the requirements as questions that can be applied to measure student learning outcomes in maritime history courses. Of the 30 questions that were compiled, 24 questions were obtained which were declared valid. This shows that the 24 questions are able to measure what is being measured. Furthermore, the results of the reliability analysis show that the hots-based questions that have been compiled have very high reliability. this means that the HOTS questions that have been compiled can be trusted to produce a stable score, relatively unchanged even though they are tested in different situations.

\section{Conclusion}

Based on the results of the research, the following conclusions were obtained: (1) the final product in this research is a HOTS-based Maritime History learning outcome test instrument that was integrated with Riau local history to measure student learning outcomes in the Maritime History course. The test instrument is in the form of a HOTS test item consisting of 24 multiple-choice questions. The question instrument was developed through three development steps, namely: (1) Define, (2) Design, and (3) develop. Based on the statistical validity test of the 30 tes questions that have been compiled, 24 items were declared valid. And based on the results of the reliability test, the HOTS-based learning evaluation instrument 
that has been developed has very high-reliability criteria. Based on some of the results above, it can be concluded that the HOTS-based learning outcome test instrument that has been developed is appropriate to be used to measure student learning outcomes in the Maritime History course at the University of Riau.

\section{Acknowledgments.}

The test instrument that has been developed in this study, is based on local History Materials taught in the department of the History Education University of Riau, and may not be suitable to be applied in another department of history education outside Riau Province.

\section{References}

[1] Asrul, et.al. Evaluasi Pembelajaran. Bandung: Citapustaka Media, 2014.

[2] Murbangun Nuswowati.et.al. Pengaruh Validitas Dan Reliabilitas Butir Soal Ulangan Akhir Semester Bidang Studi Kimia Terhadap Pencapaian Kompetensi.Jurnal Inovasi Pendidikan Kimia. Vol 4, No 1 (2010).pp.566-573

[3] Amarulla Octavian dan Bayu A. Yulianto. Degradasi Kebudayaan Maritim: Sejarah, Identitas, Dan Praktik Sosial Melaut Di Banten. Jurnal Masyarakat Indonesia. Vol 40, No 2 (2014).pp.159-176.

[4] Syafii, I. SEJARAH LOKAL ADALAH SEJARAH MARITIM (NASIONAL) INDONESIA?. Sejarah dan Budaya : Jurnal Sejarah, Budaya, dan Pengajarannya, 11(1)(2017), pp.24-36. doi:10.17977/um020v11i12017p024

[5] Fauzan Rikza. Penulisan Sejarah Lokal Indonesia (Wacana Magis-Religio Hingga Pendekatan Multidimensional). Prosiding Seminar Nasional Pendidikan FKIP Vol. 3, No.1, 2020, pp. $367-$ 375

[6] Warto, W. Tantangan Penulisan Sejarah Lokal. Sejarah dan Budaya : Jurnal Sejarah, Budaya, dan Pengajarannya, 11(1).2017, pp.123-129. doi:10.17977/um020v11i12017p123

[7] Supardi. Pendidikan Sejarah dalam Konteks Multilultural. Cakrawala Pendidikan, Februari 2006,Th.XXV, No. 1 . doi:10.21831/cp.v0i1.395

[8] Kamaruddin K, Ahmal A. The study of history based on local antiquity: A case study of existence of Kampar River in analyzing the past maritime in teaching history.. Journal of Educational Sciences. Vol. 2, No. 1, 2018, pp.72-78. doi:10.31258/jes.2.1.p.72-82

[9] Murdi, Lalu. Sejarah Lokal Dan Pendidikan Karakter (Tinjauan Dalam Kearifan Lokal Masyarakat Sasak Lombok). Fajar Historia Volume 1 Nomor 1, Juni 2017, pp. 42-54. . doi:10.29408/fhs.v1i1.580

[10] Hariyono H. Sejarah Lokal: Mengenal yang Dekat, Memperluas Wawasan.:Jurnal Sejarah, Budaya, dan Pengajarannya, 11(2)(2017).pp. 160-166. doi:10.17977/um020v11i22017p160

[11] Romadi R, Kurniawan GF. PEMBELAJARAN SEJARAH LOKAL BERBASIS FOLKLORE UNTUK MENANAMKAN NILAI KEARIFAN LOKAL KEPADA SISWA. Sejarah dan Budaya : Jurnal Sejarah, Budaya, dan Pengajarannya, 11(1)(2017).pp.79-94. doi:10.17977/um020v11i12017p079 
[12] Rayinda Dwi Prayogi, Rio Estetika. Kecakapan Abad 21: Kompetensi Digital Pendidik Masa Depan. Jurnal Manajemen Pendidikan - Vol. 14, No. 2, Desember 2019.pp.144-151

[13] Afandi, Sajidan, Akhyar M, Suryani N. Development frameworks of the Indonesian partnership 21 st -century skills standards for prospective science teachers: A Delphi study. J Pendidik IPA Indones. 2019.pp. 89-100. doi:10.15294/jpii.v8i1.11647

[14] Gozali I, Lie A, Tamah SM, Jemadi F. HOTS questioning ability and HOTS perception of language teachers in Indonesia. INDONESIAN JOURNAL OF APPLIED LINGUISTICS Vol. 11 No. 1, May 2021, pp. 60-71. doi:10.17509/ijal.v11i1.34583

[15] Wahidmurni. Pengembangan penilaian untuk mengukur kemampuan berpikir tingkat tinggi (Higher Order Thinking Skills/HOTS). Work Pengemb Penilai Kurikulum 13 Bagi Guru-Guru Madrasah Aliyah Negeri Batu. 2018.

[16] Gorbi Irawan A, nyoman Padmadewi N, Putu Artini L. Instructional materials development through 4D model. SHS Web Conf. 2018. doi:10.1051/shsconf/20184200086

[17] Surapranata, S. Analisis, Validitas, Reliabilitas dan Interpretasi Hasil Tes: Implementasi Kurikulum. Bandung: PT Remaja Rosdakarya , 2005

[18] Hendryadi H. VALIDITAS ISI: TAHAP AWAL PENGEMBANGAN KUESIONER. $J$ Ris Manaj dan Bisnis Fak Ekon UNIAT. 2017.pp.169-178. doi:10.36226/jrmb.v2i2.47

[19] Komarudin, Sarkadi. Evaluasi Pembelajaran. Jakarta: laboratorium Sosial Politik Press, 2017

[20] Sudijono, Anas. Pengantar Evaluasi Pendidikan. Jakarta: Rajawali Press, 2018

[21] Haryanto. Evaluasi Pembelajaran (Konsep dan Manajemen).Yogyakarta: UNY Press, 2020.

[22] Sutanto, Purwadi. Modul Penyusunan Soal Keterampilan berpikir Tingkat Tinggi (Higher Order Thinking Skill). Jakarta: Direktorat Pembinaan Sekolah Menengah Atas, 2017. 